\title{
Active Listening Strategies of Academically Successful University Students
}

\author{
Murat CANPOLAT 1 \\ Sekvan KUZU2 \\ Bilal YILDIRIM ${ }^{3}$ \\ Sevilay CANPOLAT ${ }^{4}$
}

Suggested Citation:

Canpolat, M., Kuzu, S., Yıldırım, B.,\& Canpolat, S. (2015). Active listening strategies of academically successful university students. Eurasian Journal of Educational Research, 60,163-180

Doi: 10.14689 /ejer.2015.60.10

\begin{abstract}
Problem Statement: In formal educational environments, the quality of student listening affects learning considerably. Students who are uninterested in a lesson listen reluctantly, wanting time to pass quickly and the class to end as soon as possible. In such situations, students become passive and, though appearing to be listening, will not use listening strategies that promote productive and permanent learning. By contrast, when students willingly participate in lessons by listening to instructors, asking questions, and holding discussions, they practice active listening that allows them to achieve more productive and more permanent learning.

Purpose of Study: The aim of this study was to identify active listening skills that academically successful university students use in classes and to analyze these students' opinions on active listening skills.

Methods: This qualitative research involved a case study by which academically successful university students were observed in a classroom environment and their thoughts on active listening skills examined.
\end{abstract}

${ }^{1}$ Lecturer, Mustafa Kemal University, Faculty of Education, Department of Educational Sciences, muratcanpolat@mku.edu.tr

${ }^{2}$ Lecturer, Mustafa Kemal University, Faculty of Education, Department of Educational Sciences, skuzu@mku.edu.tr

${ }^{3}$ Research Assistant, Mustafa Kemal University, Faculty of Education, Department of Primary Education, byildirim@mku.edu.tr

${ }^{4}$ Teacher, Ministry of Education, sevilayborazan@hotmail.com 
According to the model, participants were evaluated without any intervention by researchers in the classroom environment.

Findings: Findings from observations and interviews were organized under three subheadings: cognitive, affective, and psychomotor-based strategies. Cognitive strategies included paying attention, taking notes, making associations and analogies, asking questions, integrating information, making inferences, getting the main idea, and setting an objective; affective strategies included attending class on time, being motivated, staying calm, and enjoying the lesson; and psychomotor-based strategies included being close to the board, following along with both the head and eyes, making eye contact, generating feedback, sitting up straight, and paying attention to gestures, facial expressions, tone of voice, and stresses in speech.

Conclusion and Recommendations: According to data collected during the study, academically successful university students used different cognitive, affective, and psychomotor-based strategies in practicing active listening.

Keywords: Active listening, university students, academic success, listening strategy

\section{Introduction}

The skill of listening is the first linguistic skill that humans acquire. In fact, fetuses hear voices outside the womb as early as the fifth month of gestation (Doğan, 2008). Perhaps given its primary placement among linguistic skills, the many definitions of listening differ. In general, however, listening comprises sending a message (i.e., transmission), hearing that message, and making sense of it (Özbay, 2005).Listening does not mean watching the other party passively, but making an effort to receive and interpret messages in order to fully achieve communication (Devito, 1995; Omololu, 1984; Umagan, 2007).

Able to become both individuals and social actors by using linguistic skills, humans hear, perceive, recognize, meet others, think, and understand by listening. As the most important means of learning in every period of human development and growth, listening has been acknowledged as fundamental among linguistic skills (Karadüz, 2010). By extension, since individuals make sense of all kinds of sounds that they hear throughout life and store them in their memory as an important part of their accumulated experiences and knowledge, listening is also fundamental in learning.

Listening's role in all of an individual's experiences with learning his or her native language expands over time. On average, approximately half of all human activities involve listening and $45 \%$ of time used for communication involves listening, as shown by research conducted by Lyman Steal at the University of Minnesota (Yildiz, Okur, Ar1, \&Y1lmaz, 2003). Furthermore, by listening to others, people meet many of their 
cognitive, affective, and social requirements such as learning, obtaining proper nutrition, communicating, speaking, and showing emotion. At the same time, a great deal of both formal and informal learning is achieved by listening, and according to Hunsaker (1990), 80\% of what people know is obtained by listening. Given the abundance of teachers who use lecture-based teaching methods in schools, the time that students spend listening increases all the more. For some students, nearly $83 \%$ of what they learn is learned by listening (Özbay, 2005; Petress, 1999). In effect, the above figures underscore the importance of listening training both at school and at home.

The acts of listening that an individual performs to meet cognitive, affective, and social requirements throughout the processes of formal and informal education are multidimensional. Listening is an activity that individuals engage in cognitive, affective, and psychomotor-based ways and, defined as a linguistic skill, should be carried out strategically and sophisticatedly in any mode of communication. In listening, individuals are not passive receivers who remain silent and submissive while information is communicated, but active receivers who present their thoughts and emotions in ways both verbal and nonverbal. Listening means understanding thoughts expressed in speech, organizing and evaluating them, determining their interrelationships, and selecting ones worth remembering (Ergin \& Birol, 2005).

In formal educational environments, the quality of student listening affects learning considerably. Students who are uninterested in a lesson listen reluctantly, wanting time to pass quickly and the class to end as soon as possible. In such situations, students become passive and, though appearing to be listening, will not use listening strategies that promote productive and permanent learning. By contrast, when students willingly participate in lessons by listening to instructors, asking questions, and holding discussions, they practice active listening that allows them to achieve more productive and more permanent learning.

In classroom environments, the ideal form of listening is active listening. Unlike passive listeners who seek solely to retain ideas in their minds, active listeners both produce thoughts and share those thoughts by expressing them in verbal and nonverbal ways. The observable external signs of active listening include physically displaying emotion, cooperating with members of the group of listeners, physically expressing approval or disapproval of what is said, exhibiting behaviors directed toward listening, asking questions about what is being said, and contributing appropriate explanations and comments (Brent \&Anderson, 1993; see also Akyol, 2012).

As part of their learning experiences throughout the processes of education, each individual develops listening strategies that are cognitive, psychomotor-based, or affective in nature. While implementing cognitive listening strategies, individuals compare and classify information in their minds, make inferences, formulize what they have learned, generate associations, reason, take notes, and make generalizations (Akyol, 2006), all for the purpose of achieving more effective and permanent learning. At the same time, listening strategies that reflect listener emotions expressed via body 
language while listening, including facial expressions, gestures, and sitting position, significantly demonstrate how listeners feel in the environment and what stance they take on what is said. By turns, listeners sympathize, empathize, and may even feel excited, scared, or stressed. Since all of these states influence an individual's listening reflexes and habits, their effective and strategic use of these actions can help to more fully realize communication, learning, thinking, hearing, and telling. Furthermore, stating that auxiliary strategies need to be used to facilitate understanding, Akyol (2006) has posited that active listeners make guesses prior to listening and continuously renew their guesses while listening according to new information and clues provided by the speaker. Another general strategy is determining the main idea, in which listeners regularly ask themselves what the point of the information provided is.

In the light of the above, we hypothesized that the development of listening skills among university students contributes to their academic success and improves their social skills. To test our hypothesis, we identified strategies used by academically successful university students by examining what kind of listeners they were in a classroom environment, as well as analyzed these students' opinions on active listening skills. In effect, the study has sought to contribute to the planning and implementation of practices that can develop students' listening skills.

\section{Method}

\section{Research Design}

This qualitative research involved a case study by which academically successful university students were observed in a classroom environment and their thoughts on active listening skills examined. According to the model, participants were evaluated without any intervention by researchers in the classroom environment (Karasar, 2000).Since making generalizations from numbers is generally beyond qualitative research, generalization was not the goal of the study, but instead a descriptive portrayal regarding the problem.

Sample

The sample was consisted of eight academically successful students selected via criterion sampling from all students in several undergraduate programs within the Faculty of Education at Mustafa Kemal University during the 2012-2013 academic year. Selection was performed based on the information gathered by faculty members who attended the students' classes and demographics. Four participants were women and four were men. It is thought that such a sample is sufficient for qualitative researches (Yıldırım \& Şimşek, 2011). 


\section{Instruments and Procedure}

During data collection, participants were first observed in a classroom environment, each during a different period, and data collected. They were then asked eight questions addressing basic strategies that they used in listening and participated in semi-structured interviews, all audio recorded, concerning their thoughts on active listening. For analysis, the sound recordings were transcribed for a total of 40 pages of text.

\section{Data Analysis}

Content analysis of the qualitative data was performed according to procedures described in the literature (Strauss \& Corbin, 1990; Yıldırım \& Şimşek, 2011). The researchers first took notes about probable codes and categories by reading data obtained via both observations and interviews. For coding - that is, the process of naming meaningful pieces of data-students' statements, concepts used in the field, and statements of researchers and experts were used as codes. The researchers continuously exchanged information with each other and experts regarding these codes and possible categories.

After the researchers completed the coding process, one researcher prepared a list of categories under which codes were placed. This list was given to the other researchers, who confirmed that the codes derived from the categories. The data of two students were coded independently by the researchers, and coherence among them was assessed to determine the consistency among the researchers given that the researchers who performed data collection also performed data analysis. Coherence among the codings was found to be $84.12 \%$ at the end of the examination, indicating that the researchers' reliability was high regarding data coding. Validity was ensured by the researchers' being continuously in contact while coding, examining the codings determined and themes found from one researcher to the next in terms of coherence with the data, and including direct quotations from participants in the findings.

Ultimately, common active listening strategies used by participants were pinpointed during content analysis and have been presented as follows. For confidentiality, participants' names have been replaced with numbers.

\section{Results}

Findings concerning the results of observations and interviews are below presented under three subheadings - namely, cognitive, affective, and psychomotorbased strategies - under the dual primary headings of observation and interview data. 


\section{Findings Concerning Cognitive Strategies}

Active listening is a cognitive process involving an array of intellectual behaviors. According to data from interviews, participating students reported that, while listening to their instructors, they tend to use cognitive strategies such as paying attention $(n=8)$, taking notes $(n=8)$, making associations and analogies $(n=7)$, asking questions $(n=7)$, integrating information and making inferences $(n=6)$, seeking the main idea $(n=4)$, and setting objectives for listening $(n=3)$.

For participants, the strategy of paying attention while listening facilitates more productive lessons and should be used frequently while listening, as the following comments exemplify:

I clear my mind and my intellect and pay attention to the instructor. If I do not want to listen, then I think about something else (Student 1).

My mind is disorganized sometimes, so I can't listen to my instructor effectively. However, when I'm paying attention to the class, I listen to the subject carefully (Student 2).

I think attention and focus are important in listening to instructors. Focusing attention is important because you don't want to focus on two different things at the same time. Otherwise, it's impossible for me to listen to instructors (Student 3).

When there's a subject that particularly attracts my attention or if examples are given, that enables me to listen more actively (Student 4).

To pay attention in class while listening, students reported needing to rid their minds of thoughts unrelated to the lesson at hand. Yet, they also admitted struggling to focus on lessons and being unable to fully participate in listening for different reasons, including being tired, being sleepy in their earliest classes, thinking about other classes, daydreaming, the instructor's failed classroom management, and even being prejudiced against the class.

Students also frequently employed the strategy of taking notes while listening to achieve more effective and more permanent learning. In note taking, they reported seeking to learn more effectively by carefully recording ideas they deem significant and classifying what they learn. As an active listening behavior, taking notes was generally described by students to afford more permanent knowledge through the use of writing. During interviews, students detailed their strategic use of taking notes, as the following represent:

While taking notes, I do not write all of the things that the instructor says, but main titles, in the form of an outline (Student 3).

I try to take notes of topics in ways that make sense to me, not everything that speaker talk about (Student 5). 
I take notes in class. I usually study with them for exams (Student 6).

If I have to take notes, I listen first, then try to take notes in the form of brief clues from what I've understood (Student 8).

I listen carefully and take notes of points that the instructor says are important (Student $1)$.

I do not write down what I listen to in the exact same way; I interpret it and write it down in my own words (Student 4).

As shown, a teacher's instructions for students to take notes clearly affect students. Expected from students in the strategy of taking notes is that they take notes of points that they deem significant and in their own words. With this practice, students can ensure that the information is repeatable and more easily remembered. As participants' answers reveal, students can develop note taking strategies that accommodate their instructors' emphasis upon certain points. Among others, taking notes in a notebook, organizing notes, and having ample space for writing are common tactics used while taking notes that can make the most of active listening.

Students interviewed reported establishing connections among topics that they have studied recently or further in the past by providing examples. Such behavior suggests that students use the listening strategy of making associations and analogies, as participants explained in their own words:

I participate in class by giving examples of the subjects that our instructor talks about (Student 7).

I try to actively participate in class, share my opinions, and ask about points that I do not understand during class (Student 8).

I try to understand the essence of the main idea of the things that the instructor talks about and look for examples related to it. I repeat all of this in my mind (Student 5).

If a subject has my interest and if I can relate it to my own life, then I can listen actively and attentively (Student 2).

Participating students stated that using the strategy of asking questions is effective both in their learning of points that they do not understand and in maintaining attention while listening to instructors, as what follows clarifies:

While an instructor is explaining, I definitely ask questions about points that I don't understand (Student 4).

I try to actively participate in the class, share my opinions, and ask about points that I don't understand during class (Student 8). 
Results indicate that students also listen strategically by integrating information and making inferences, meaning that they try to create meaning of what they have listened to. Students who use these strategies are not passive receivers in listening, but evaluators of meanings that they create via active intellectual participation. Since the process of listening is a process of reasoning, active listeners question what they listen to, make inferences, and ultimately create meaning. Participants' comments concerning the strategy of integrating information and making inferences appear below:

I compare the subject being related to those I already know. I deliberate over concepts, associate, and think critically (Student 3).

I compare what I know with what I hear, and I make inferences (Student 4).

I compare what I'm listening to with information that I've learned before. I ask questions at points when there is inconsistency, and I criticize (Student 5).

Seeking the main idea also ranks among strategies articulated by the participating students, who emphasized that the tactic wards off distraction from lessons and focuses attention on instructors. In general, they additionally agreed that the strategy plays a positive role in learning:

I try to understand the essence of the main idea of the things that the instructor talks about and look for examples related to it. I repeat all of this in my mind (Student 4).

I feel the need to listen to the instructor because I want to find the main idea (Student 7).

I try to discern the logic of the lesson, and I believe that learning is more permanent this way (Student 8).

In any case, however, interests and needs determine the process of listening as well. When individuals listen for what they need, they have set objectives and listen selectively. The following comments showcase the strategy of setting listening objectives:

For me to listen actively, I need to need that information. It must excite me (Student 5).

I try to listen for what will be beneficial for me in exams in the future (Student 7).

\section{Findings Concerning Affective Strategies}

To be effective in learning environments, learning must be addressed in all of its dimensions, one of which encompasses the affective properties, including emotions, that individuals experience while learning. Among all active learning strategies, these are known as affective strategies. 
When learners exhibit positive affective behaviors while listening, active listening is realized in a more careful and motivated way. Researchers have shown that individuals who are motivated and eager to listen are more active while listening, whereas individuals who feel pressured by having to listen or who are shy became passive-in other words, less successful learners (Karadüz, 2010). Students interviewed stated that when they listen willingly, they enjoy learning, yet when they feel pressured and listen in fear, they cannot learn effectively or permanently. According to data gathered from the interviews in the present study, students demonstrated affective behaviors such as attending class on time $(n=7)$, being motivated $(n=6)$, being calm $(n=5)$, enjoying the lesson $(n=5)$, and being bored $(n=$ $3)$. Some students explained how they use affective listening strategies, as shown below:

If a subject doesn't appeal to me, even if I listen, I won't understand anything (Student 1).

When subjects that I don't like are discussed in class, I find it hard to listen to my instructor (Student 8).

I become motivated and more eager in subjects that interest me, and I enjoy listening to those instructors (Student 7).

I'm usually calm, but if I'm listening inattentively, then I get nervous with the fear that the instructor may ask me a question (Student 1 ).

If the instructor has a stern attitude, then I become nervous. If the subject appeals to me, then I become eager (Student 4).

I get agitated when I feel that I don't understand (Student 2).

I definitely get to classes 5 to 10 minutes before the instructor does (Student 6).

I don't think that I can concentrate on the lesson if I come to class late (Student 5).

Students reported being unable to develop any strategy in terms of affectivity when faced with authoritarian and stern attitudes, which stifle authentic attitudes and propagate pressure. In these cases, they prefer remaining silent in a panicked, anxious state void of self-confidence. By contrast, they reported listening willingly and happily and even feeling excited by being more comfortable and allowed to feel authentic, daydream, be in the moment, and participate in the process of listening with rich, genuine emotion. At the same time, students who attend class on time stated that doing so allows them to prepare themselves affectively prior to listening, to not miss the beginning of the lesson, and to concentrate better. 


\section{Findings Concerning Psychomotor-Based Strategies}

Among activities of active listening, psychomotor-based strategies are crucial. Students' interest in, desire for, and attention toward lessons can easily fluctuation according to the success of psychomotor strategies. According to data collected in the present study's interviews, students indicating using psychomotor-based behaviors such as being close to the board $(n=7)$, following along with both their head and eyes $(n=6)$, making eye contact $(n=6)$, generating feedback $(n=6)$, sitting up straight $(n=$ 6), paying attention to gestures, facial expressions, tone of voice, and stresses in speech $(n=6)$, and doing something else $(n=4)$.Some students expressed their thoughts on psychomotor-based strategies in the following comments:

While listening, I generally prefer looking at the face of the person in front of me, taking notes while listening to them, and asking about points that I wonder about (Student 2).

I direct all of my attention to the person talking by looking into the instructor's eyes, by nodding, by using body language, and by supporting points with my eyes and facial expressions (Student 6).

Gestures, facial expressions, and tone of voice are all required to attract students' attention, and it's understood that instructors emphasize important points to pay attention to (Student 3).

I pay attention to instructors' stresses, use of repetition, and tone of voice when they're explaining the subject (Student 8).

If there's too much noise in the class, I prefer sitting in the front row so that I can listen to the instructor (Student 8).

I usually try to sit alone, because I don't like talking to classmates next to me during class that much (Student 5).

When I am bored with the class, I spin a pen in my hand (Student 4).

While listening to instructors, I don't do anything else and sit up straight at my desk (Student 3).

In general, students try to make eye contact with their instructors while listening. Eye contact - the basis of communication that makes other speakers feel that they are being listened to-is pivotal in listening training as well. Students who make eye contact with instructors can also follow their instructors' gestures and facial expressions while listening. They can also interpret their instructors by effectively understanding body language, gestures and facial expressions.

By the same token, another function of eye contact is feedback. Students can give instructors feedback about the subjects being discussed in terms of whether they 
understand by making eye contact with instructors, often supported by movements of the head. With this feedback, instructors can make necessary corrections.

Another point mentioned by students during interviews concerned sitting up straight. In fact, the method of listening to instructors by sitting up straight and not doing anything else accepted as correct in the Turkish education system was also applied by students who participated in this study. Yet, it should be remembered that students in this state are nevertheless passive listeners. Students should also be provided with the opportunity to participate in class during activities so that knowledge communicated can be learned more effectively and permanently.

Sitting close to the board was another tactic mentioned during interviews. Participating students stated that when they sat close to the board, they were closer to the instructor and noise did not hinder their listening. They also reported that they could not listen to instructors from the furthest rows because there was too much noise, which some students attributed to the instructor's failed classroom management.

Some participants also highlighted negative listening tactics. Doing something else while listening facilitated their distraction, for example. Whether students exhibit these behaviors constantly or rarely is important feedback for instructors, for students who demonstrate these behaviors typically suggest that they have become bored with the class. From these messages, instructor can make opportunities for interventions in the course of the class. At the same time, students who exhibit this behavior constantly have generally lost interest in the class and need special attention.

\section{Results of Observation}

As shown in Table 1, students used the cognitive strategies of paying attention, taking notes, making associations and analogies, and asking questions while listening; and the affective strategies of attending class on time and being calm while listening to the instructor, as well as were interested in, eager about, and motivated to understand the subject, yet after a certain amount of time, especially in the last 10 to 15 minutes of the class, got bored. Furthermore, among psychomotor-based strategies, students used positive ones such as sitting close to the board, following the instructor with both the head and eyes, making eye contact with the instructor, and sitting up straight, as well as ones that showed they were bored with the class - namely, by doing other things. 
Table 1.

Findings from the Results of Observations

\begin{tabular}{|c|c|}
\hline Themes Codes & $\mathbf{f}$ \\
\hline \multicolumn{2}{|l|}{ Cognitive } \\
\hline Paying attention & 8 \\
\hline Taking notes & 7 \\
\hline Making associations and analogies & 5 \\
\hline Asking questions & 4 \\
\hline \multicolumn{2}{|l|}{ Affective } \\
\hline Attending class on time & 7 \\
\hline Being calm & 7 \\
\hline Being motivated & 6 \\
\hline Being bored & 3 \\
\hline
\end{tabular}

Psychomotor

Being close to the board $\quad 7$

Following along with the head and eyes $\quad 5$

Making eye contact 5

Sitting up straight $\quad 5$

Doing something else 2

Below are statements purporting participants' use of cognitive, affective, and psychomotor-based strategies observed in the classroom environment:

The student started to write down what the instructor said in his notebook from the moment the class started (Student 1 , coded as taking notes).

The student asked "What is the difference between shaping and threshold method? (Student 2, coded as asking questions).

There were 2 minutes before the class started. The student came in, sat at the second desk in middle row, and took out pen and notebook (Student 3, coded as attending class on time). 
The student got distracted, looked at her watch now and then, and started to turn to her left and right (Student 4 , coded as being bored and doing something else).

The student listened to the instructor attentively, made eye contact, followed the instructor, and approved what the instructor said by nodding (Student 5, coded as making eye contact and following along with the head and eyes).

\section{Discussion and Conclusion}

A listening culture in which students are made passive has persisted for years in primary education. As part of this culture, a preference for students who listen to the teacher quietly, sit still, and do not make noise in learning environments has partially rendered students unable to develop linguistic skills such as listening and to selfactualize. Yet, the process of listening is a multidimensional one in which individuals participate with nonverbal and verbal language, thoughts, and emotions. As they do in their social lives, learners should use linguistic skills in formal learning environments and be able to actualize their linguistic skills without feeling pressured. The pressures of failing and of being unable to express ideas well can stifle their natural behaviors and promote their developing into individuals deprived of basic skills.

Karadüz (2010) has found that students do not use listening strategies that are too multifarious. Using limited stimulation in learning environments, being rendered passive in traditional education systems, and being unable to develop sufficient strategies can cause them to become individuals who only take notes, listen to the instructor quietly, are shy about objecting, and cannot develop alternative ideas (Karadüz,2010). Other than the verbal channel, by which students can express themselves in multiple learning activities, listening environments should also allow other senses to be used as well. Though most classroom communication revolves around instructor's speeches, the four sensory channels other than listening - namely, sight, touch, taste, and smell - can facilitate or hinder learning in normal classrooms. As such, new forms of stimulation can be provided by shifting sensory channels, though realizing such changes requires students to be primed for those sensory experiences. If done well, then the approach can refocus students' attention back to the instructor's presentation (Kenneth, 1999).

To obtain correct and complete information in listening environments, listeners needs to adopt an attitude of listening in a natural, comfortable way. According to Özbay (2001), instructors can best succeed in communicative listening training by offering opportunities that make it possible for students to learn via experience.

Since students listen in ways that are more directed toward succeeding on examinations, they adopt a pragmatic attitude while taking notes in classes. Instead of seeing learning as a natural need, they prefer listening for information that they 
suspect will be useful on examinations. However, the popularity of such a strategy implies that classes do not accommodate listening processes directed toward communication, but a culture in which selective listening predominates. Students cannot listen to instructors in such environments, because they are distracted when they are uninterested. However, to be able to communicate, students need to develop their skills of extraordinary view and critical listening (Stone,1994).

In any listening environment, many strategies are available such as setting objectives, preparing oneself mentally, guessing, using key concepts, and taking notes that determine the type, method, and technique of listening (Güneş, 2007; Worthington 2008) and whether it is effective.

According to data obtained from this study, academically successful university students used different cognitive, affective, and psychomotor-based strategies to achieve active listening. Students generally used cognitive strategies such as paying attention, taking notes, making associations and analogies, asking questions, integrating information, making inferences, seeking the main idea, setting objectives; affective strategies such as attending class on time, being motivated, being calm, and enjoying the lesson; and psychomotor-based strategies such as being close to the board, following along with both the head and eyes, making eye contact, generating feedback, sitting up straight, and paying attention to gestures, facial expressions, tone of voice, and stresses in speech. At the same time, among negative psychomotor-based strategies, students expressed being bored and doing other things while listening. In this sense, several factors contribute to active listening in listening-oriented learning environments, including how eager students are to learn the lesson, to what extent they pay attention to the lesson, their preparedness, their mood, whether they like the subject, whether they attend class on time, the desk that they sit at, and its surroundings.

In sum, active listening is a multidimensional process that involves various cognitive, affective, and psychomotor-based elements. Identifying and making use of these elements in natural, democratic learning environments supports student learning and their acquisition of diverse social skills. Executing linguistic skills not with an information-oriented but skill-oriented learning culture contributes to individuals' development of emotions and thoughts, as well as of skills of understanding and explaining. Learning-teaching cultures in which students are kept in a passive state prevent them from exhibiting these skills. Individuals held in check exhibit affective characteristics of being passive and lacking confidence in their knowledge and ideas. Learning environments should thus be designed according to learning approaches in which social skills are developed, students are active, and learning tasks are devised according to students' interests and abilities. It is important that each student develops the strategy of listening during primary education and can use many types of listening to that end, as well as that activities directed toward skills of listening are sufficiently included in learning environments. Accordingly, listening environments in which individuals are sufficiently motivated and stimulated need to be designed within learning environments. These environments should ensure that 
along with verbal stimulations, factors that appeal to other sensory channels are accommodated in order to maintain and even improve students' attentiveness.

\section{References}

Akyol, H. (2006). Yeni programa uygun türkçe öğretim yöntemleri [Turkish teaching methods appropriateto the new program]. Ankara: Kök Yayıncılık.

Akyol, H. (2012). Programa uygun türkçe öğretim yöntemleri[Turkish teaching methods appropriate to the program]. Ankara: Pegem Akademi Yayıncilılık.

Devito, J. A. (1995). The interpersonal communication book. New York, NY: Harper Collins CollegePublishers.

Doğan, Y. (2008). İlköğretim yedinci sınıf öğrencilerinin dinleme becerilerini geliştirmede etkinlik temelli çalışmaların etkililiği [Efficacy of activity-based studies on improving the listening skills of seventh-grade students].Türk Ĕgitim BilimleriDergisi, 6(2), 261-286.

Ergin, A.,\& Birol, C. (2005). Eğitimde iletişim [Communicationin education]. Ankara: Anı Yayıncilik.

Güneş, F. (2007). Türkçe öğretimi ve zihinsel yapılandırma[Turkish education and mental configuration]. Ankara: Nobel Yayınları.

Hunsaker,R.A.(1990).Understandinganddevelopingtheskillsoforalcommunication:Speakinga ndlistening(2nded.). Englewood, CO: J. Morton Press.

Karadüz, A. (2010). Türkçe ve sınıf öğretmeni adaylarının dinleme stratejilerinin değerlendirilmesi [The evaluation of listening strategies of Turkish-language and primary student teachers].Erciyes Üniversitesi Sosyal Bilimler Enstitüsü Dergisi, 29, 39-55.

Karasar, N. (2000). Bilimsel araştırma yöntemi[Research methodology](12th ed.). Ankara: Nobel Yayın Dağıtım.

Moore, K. D.(1999). Öğretim becerileri [Classroom Teaching Skills](Ersin Altıntaş,Ed., N. Kaya,Trans.). Ankara: Nobel Yayıncılık.

Omololu, C.B. (1984). Communication behaviours of undergraduate medical students before and after training. British Journal of Medical Psychology, 57, 97-100.

Özbay, M. (2001). Türkçe öğretiminde dinleme becerisini geliştirme yolları [Ways to improve listening skills in teaching Turkish]. Türk Dili Dergisi, 589, s. 9-15. 
Özbay, M. (2005). Bir dil becerisi olarak dinleme eğitimi [Listening training as a language skill]Ankara: Akçă̆ Yayınları.

Petress,C.K.(1999). Listening: A vital skill. Journal of Instructional Psychology, 26(4), 261262.

Stone, J. (1994).Cooperative learning and language arts. San Clemente, CA: Kagan.

Strauss, A.,\& Corbin, J. (1990). Basics of qualitative research: grounded theory procedures and technique. London: Sage.

Umagan, S. (2007). Dinleme eğitimi [Listening training].H. Akyol\& H. Kırkkılıç (Eds.), Ilköğretimde Türkçe öğretimi[Teaching Turkish in elementary school]. Ankara: Pegema Yayıncilik.

Worthington,D.(2008).Exploring the relationship between listening style and need for cognition. International Journal of Listening, 22, 46-58.

Yıldırım, A.,\&Şimşek, H. (2011). Sosyal bilimlerde nitel araştırma yöntemleri [Qualitative research methodsin the social sciences] (8th ed.).Ankara: Seçkin Yayınevi.

Yıldız, C., Okur, A., Arı, G.,\&Yılmaz, Y.(2008). Yeni öğretim programına göre kuramdan uygulamaya türkçe öğretimi [Turkish education from theory into practice according to the new curriculum]. Ankara: Pegema Yayınları.

\section{Akademik Yönden Başarılı Üniversite Öğrencilerinin Aktif Dinleme Stratejilerinin Değerlendirilmesi}

Atıf:

Canpolat, M., Kuzu, S., Yıldırım, B.,\& Canpolat, S. (2015). Active listening strategies of academically successful university students. Eurasian Journal of Educational Research, 60,163-180

Doi: 10.14689 /ejer.2015.60.10

\section{Özet}

Problem Durumu: Dinleme becerisi insanın kazandığı ilk dil becerisidir. Bebeklerin anne karnında 5. aydan itibaren dışarıdaki sesleri duydukları bilinmektedir. Temel dil becerileri arasında ilk ve en fazla kullanılan dinleme becerisinin tanımı alanın araştırmacıları tarafından farklı şekillerde yapılmıştır. Dinleme mesaj gönderme (iletme), mesajı işitme (duyma) ve mesajın anlamlandırılmasından oluşmaktadır. Bunlar dinlemenin özellikleridir. Dinleme, karşı tarafı edilgen bir yapıda izleme değil, iletişimin tam olarak gerçekleşebilmesi için iletiyi alma ve yorumlama çabasıdır. 
Bireyin ana dilini edinme süreciyle geçirdiği bütün öğrenme yaşantılarında dinleme becerisinin rolü gitgide artmaktadır. Ortalama olarak insan faaliyetlerinin yarısına yakını dinlemekle geçer. Minnesota Üniversitesi'nden Dr. Lyman K. Steal'in dinleme ile ilgili yaptığı araştırmasında iletişime ayrılan sürenin \%45'i dinlemeyle geçmektedir. İnsanlar öğrenme, beslenme, iletişim kurma, konuşma, duygulanma vs gibi birçok bilişsel, duyuşsal, sosyal vs. gibi gereksinimlerini birbirlerini dinleyerek karşılarlar. Formal ve informal öğrenmelerin büyük bölümü dinlemeyle geçirilmektedir. Bu durum dinleme eğitiminin hem okulda hem de ailede yeterince önemsenmesi anlamına gelmektedir. Okullarımızda öğretmenlerin pek çoğu düz anlatım yöntemini kullanmaktadır. Bu durumda öğrencilerin dinlemeye ayırdıkları zaman daha da artmakta, öğrenciler öğrendiklerinin neredeyse \%83'ünü dinleme yoluyla elde etmektedirler.

Formal eğitim ortamlarında dinlemenin niteliği öğrenmeyi önemli ölçüde etkilemektedir. Derse ilgi duymayan bir öğrenci gönülsüz dinlemekte, zamanın çabuk geçmesini düşünerek dersin bir an önce bitmesini isteyebilmektedir.. Bu tür durumlarda öğrenciler pasif, görünüşte dinleyici durumundadırlar. İlgi duymadı̆̆ı, dikkatinin çekilmediği bir durumda bireyin kalıcı ve verimli öğrenmeler geçireceği dinleme stratejileri kullanması düşünülemez. Bazen de öğrenciler derse istekle katılıp tartışmakta, öğretmeni dinlemekte, sorular sormaktadırlar. Bu gibi durumlarda ise aktif dinleme gerçekleşir ve öğrenciler daha kalıcı ve verimli öğrenmeler gerçekleştirirler.

Araştırmanın Amacı: Bu araştırmanın amacı akademik yönden başarılı üniversite öğrencilerinin derslerde kullandıkları aktif dinleme becerilerinin tanımlanması ve bu öğrencilerin aktif dinleme becerisi üzerine görüşlerini incelemektir.

Araştırmanın Yöntemi: Çalışma, akademik yönden başarılı üniversite öğrencilerinin sınıf ortamında gözlenip yine aynı öğrencilerin aktif dinleme becerisi üzerine görüşlerinin incelendiği tarama modelinde nitel bir araştırmadır. Tarama modelinde, araştırmaya katılanlar içinde bulundukları koşullara herhangi bir müdahale yapılmadan oldukları gibi değerlendirilir.

Bulgular: Araştırmadan elde edilen gözlem ve görüşme sonuçlarına ilişkin bulgular gözlem ve görüşme ana başlıkları altında bilişsel, duyuşsal, ve devinişsel stratejiler olmak üzere üç alt başlık altında sunulmuştur.

Aktif dinleme birçok zihinsel davranışları içeren bilişsel bir süreçtir. Yapılan görüşmelerle elde edilen verilere göre öğrenciler ders dinlerken daha çok dikkatini verme $(n=8)$, not tutma $(n=8)$, ilişkilendirme ve benzetim $(n=7)$, soru sorma $(n=7)$, birleştirme ve çıkarımda bulunma $(n=6)$, ana fikri yakalama $(n=4)$, amaç belirleme (n =3) gibi bilişsel stratejiler kullandıklarını ifade etmişlerdir.

Yapılan görüşmelerde elde edilen verilere göre öğrenciler daha çok derse zamanında katılım $(n=7)$, motivasyon $(n=6)$, sakin olma $(n=5)$, beğenme $(n=5)$, sikılma $(n=3)$ gibi duyuşsal davranışları ifade etmişlerdir. 
Yapılan görüşmelerde elde edilen verilere göre öğrenciler daha çok tahtaya yakın olma $(n=7)$, baş ve gözle takip etme $(n=6)$, göz teması kurma $(n=6)$, geri bildirim $(n=6)$, dik oturma $(n=6)$, jest, mimik, ses tonu ve vurgulara dikkat $(n=6)$, başka şeyle ilgilenme $(n=4)$ gibi devinişsel davranışlar ifade etmişlerdir.

Yapılan gözlem sonucunda öğrencilerin bilişsel stratejilerden sırasıyla dikkatini verme, not tutma, ilişkilendirme ve benzetim, soru sorma stratejilerini kullandıkları gözlenmiştir.

Sonuç ve Öneriler: Araştırmadan elde edilen verilere göre akademik yönden başarılı üniversite öğrencilerinin aktif dinlemede farklı bilişsel, duyuşsal ve devinişsel stratejiler kullandıkları görülmüştür. Öğrencilerin genelde dikkatini verme, not tutma, ilişkilendirme ve benzetim, soru sorma, birleştirme, çıkarımda bulunma, ana fikri yakalama, amaç belirleme gibi bilişsel stratejiler; derse zamanında katılım, motivasyon, sakin olma, beğenme gibi duyuşsal stratejiler; tahtaya yakın olma, baş ve gözle takip etme, göz teması kurma, geri bildirim, dik oturma, jest, mimik, ses tonu ve vurgulara dikkat etme gibi devinişsel stratejileri kullandıkları bulunmuştur.

Öğrenme ortamları, sosyal becerilerin geliştirildiği, öğrencilerin aktif olduğu, ilgi ve yeteneklerine göre öğrenme görevlerinin verildiği öğrenme yaklaşımlarına göre tasarlanmalıdır. Öğrenme ortamlarında dinleme becerisine yönelik etkinliklere yeterince yer verilerek her öğrencinin temel eğitimden itibaren dinleme stratejisi geliştirmesi, dinlemenin birçok çeşidini amacına yönelik olarak kullanabilmesi önemlidir.

Anahtar kelimeler: Aktif dinleme, üniversite öğrencileri, akademik başarı, strateji 